\title{
Analysis of causes of maternal mortality in tertiary care center, 11 years study
}

\author{
Vandana R. Saravade*, Munira Ansari, Ganesh Shinde
}

Department of Obstetrics and Gynecology, Topiwala National Medical College, Mumbai, Maharashtra, India

Received: 27 July 2021

Accepted: 17 August 2021

\section{*Correspondence:}

Dr. Vandana R. Saravade,

E-mail: vandanasaravade@gmail.com

Copyright: (c) the author(s), publisher and licensee Medip Academy. This is an open-access article distributed under the terms of the Creative Commons Attribution Non-Commercial License, which permits unrestricted non-commercial use, distribution, and reproduction in any medium, provided the original work is properly cited.

\begin{abstract}
Background: Objectives to study the causes of maternal mortality and the complications leading to maternal death. Methods: A retrospective study of hospital records and death summaries of all maternal death over a period of 11 years from January 2008 to December 2018 was carried out at tertiary care hospital, Mumbai.

Results: There were a total of 459 maternal death out of 36930 live birth giving maternal mortality rate mean maternal mortality ratio (MMR) of 1242 per 100000 live births. Unregistered and late referral account for maternal death. The majority of women were in 21-30 years age group in 20 to less than 37 weeks of pregnancy. The commonest cause of death was due to hepatitis infection 129 (28.1\%), sepsis 52 (11.32\%), PIH including eclampsia 46 (10.02\%), cardiovascular diseases 33 (7.18\%), haemorrhage 31 (6.75\%), Kochs $31(6.75 \%)$ and respiratory diseases $22(4.79 \%)$. Conclusions: Maternal mortality can be reduced by identifying causes which are preventable and giving timely treatment.
\end{abstract}

Keywords: Maternal mortality, Tertiary care hospital, Direct causes, Indirect causes

\section{INTRODUCTION}

Death of women while pregnant or within 42 days of termination of pregnancy irrespective of the duration and site of pregnancy from any cause related to or aggravated by pregnancy or its management but not from accidental or incidental causes. Direct obstetric death is due to obstetric complications in pregnant state. Indirect obstetric death is resulting from previous existing disease or which are aggravated by physiologic effect of pregnancy. ${ }^{1}$

United Nation on report on Millennium development goal5 concluded that the progress shown by the South Asian countries including India which accounts for $25 \%$ of all maternal deaths in world is not impressive. The United Nations issued Millennium development goals (MDG-5); emphasized on reduction of MMR by $75 \%$ between 1990 and $2015 .^{2-4}$ For India, this implies that it should have achieved the target of reducing maternal deaths to 109 , by
2015 and has an MMR of 167. The aim of study was determining the MMR in the tertiary care center and find out causes of maternal deaths.

\section{Aims and objective}

The aim and objective of the study to estimate the maternal mortality ratio at the tertiary care hospital for period of 11 years, to find out the causes leading to maternal death and to suggest prevention and control measures.

\section{METHODS}

The study was conducted in department of gynecology and obstetrics at BYL Nair hospital and T. N. medical college, Mumbai. This is a tertiary care centre catering district hospital, rural hospital and PHCs and private hospital in Thane and Palghar and adjoining states. This was a retrospective study conducted by reviewing the medical 
records and facility based maternal death report review forms for deaths over a period from January 2008 to December 2018. The maternal death was analyzed in the monthly meeting in department by senior faculty members. Every maternal death was scrutinized from various aspect likely to be related to death, such as age, parity, locality of residence, antenatal care and cause of death. MMR estimated with the formula.

MMR $=$ total no of maternal death $\times 100000 /$ Total no of live births.

As this is retrospective observational study, frequency and percentage calculations were used in statistical analysis.

Study is conducted after approval from ethical committee.

\section{Inclusion criteria}

All pregnant women irrespective of gestation age and postpartum within 42 days of delivery registered or unregistered who died due to direct or indirect causes in tertiary care hospital will be included in the study.

Death due to ectopic pregnancy.

\section{Exclusion criteria}

Coincidental maternal deaths like suicide and accidental deaths.

\section{RESULTS}

During study period, there were 459 maternal deaths out of 36930 live births giving a mean MMR of 1242 per 100000 live births. $48.58 \%$ of the death were in postnatal period. It was seen amongst the referral cases. They were transported late to Nair hospital. 108 ambulance services were strengthening from 2014 in Maharashtra. This facilitated early referral of the patients. As shown in Table 2, $8.93 \%$ were registered at our hospital. $84.53 \%$ were referred (at least 3 visits) and $6.54 \%$ unregistered. Most of the women were in prime reproductive age 21-30 years of age $75.38 \%$. Most women were multiparous $64.05 \%$.

Analysis of cause of death revealed that hepatitis was leading cause of death which is an indirect cause of maternal mortality. Out of total 459 maternal deaths, deaths due to hepatitis were $129(28.10 \%)$, sepsis due to late referral $52(11.32 \%)$, PIH with eclampsia 46 (10.02\%), cardiac disease $33(7.18 \%)$, Kochs $31(6.75 \%)$, obstetric hemorrhage $31(6.75 \%)$ [includes PPH 23 (5.01\%), atonic PPH, $8(1.74 \%)$, rupture uterus $5(1.11 \%)$, LSCS complication with DIC $2(0.44 \%)$, trauma 4 $(0.87 \%)$, adherent placenta $1(0.22 \%)$, APH $5(1.11 \%)$, ruptured ectopic $2(0.44 \%)$ vesicular mole $1(0.21 \%)]$ and infections $24(5.23 \%)$. Other causes were medical diseases involving respiratory, liver, renal and central nervous system.
Table 1: Year wise maternal mortality ratio.

\begin{tabular}{|llll|}
\hline Years & Maternal deaths & Live births & MMR \\
\hline $\mathbf{2 0 0 8}$ & 17 & 2063 & 824 \\
\hline $\mathbf{2 0 0 9}$ & 18 & 2551 & 705 \\
\hline $\mathbf{2 0 1 0}$ & 46 & 2854 & 1611 \\
\hline $\mathbf{2 0 1 1}$ & 46 & 3041 & 1512 \\
\hline $\mathbf{2 0 1 2}$ & 44 & 3495 & 1258 \\
\hline $\mathbf{2 0 1 3}$ & 30 & 4487 & 668 \\
\hline $\mathbf{2 0 1 4}$ & 55 & 3983 & 1380 \\
\hline $\mathbf{2 0 1 5}$ & 68 & 4000 & 1700 \\
\hline $\mathbf{2 0 1 6}$ & 51 & 3460 & 1473 \\
\hline $\mathbf{2 0 1 7}$ & 46 & 3454 & 1331 \\
\hline $\mathbf{2 0 1 8}$ & 38 & 3542 & 1072 \\
\hline & 459 & 36930 & 1242 \\
\hline
\end{tabular}

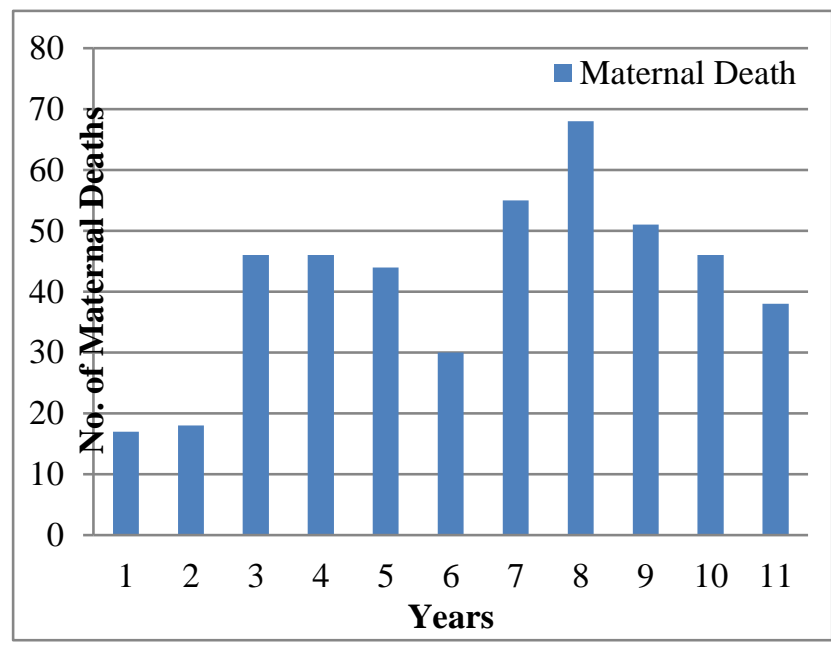

Figure 1: Maternal death.

Table 2: Socio demography distribution among maternal death.

\begin{tabular}{|c|c|c|c|}
\hline Variables & Groups & $\begin{array}{l}\text { Maternal } \\
\text { death }\end{array}$ & $\%$ \\
\hline \multirow{4}{*}{ Age (Years) } & $\leq 20$ & 57 & 12.42 \\
\hline & $21-30$ & 346 & 75.38 \\
\hline & $31-40$ & 56 & 12.2 \\
\hline & $\geq 41$ & 0 & 0 \\
\hline \multirow{2}{*}{ Parity } & Primi & 165 & 35.95 \\
\hline & Multi & 294 & 64.05 \\
\hline \multirow{3}{*}{$\begin{array}{l}\text { Antenatal } \\
\text { care }\end{array}$} & Registered & 41 & 8.93 \\
\hline & Referred & 388 & 84.53 \\
\hline & Unregistered & 30 & 6.54 \\
\hline \multirow{3}{*}{ Occupation } & Unskilled & 358 & 78 \\
\hline & Skilled & 96 & 21 \\
\hline & Professional & 5 & 1 \\
\hline \multirow{4}{*}{ Education } & Illiterate & 68 & 15 \\
\hline & Primary & 212 & 46.2 \\
\hline & Secondary & 134 & 29.2 \\
\hline & Graduate & 45 & 10 \\
\hline \multirow{3}{*}{$\begin{array}{l}\text { Economic } \\
\text { status }\end{array}$} & Low class & 312 & 68 \\
\hline & Middle class & 138 & 30 \\
\hline & High class & 9 & 2 \\
\hline
\end{tabular}


Table 3: Causes of maternal death, $(n=459)$.

\begin{tabular}{|c|c|c|}
\hline Causes & No. & Percentage (\%) \\
\hline Direct & 164 & 35.76 \\
\hline Hemorrhage & 31 & 6.75 \\
\hline Atonic & 8 & 1.74 \\
\hline APH & 5 & 1.11 \\
\hline Uterine rupture & 5 & 1.11 \\
\hline $\begin{array}{l}\text { Trauma } \\
\text { cervix/perineum }\end{array}$ & 4 & 0.87 \\
\hline $\begin{array}{l}\text { Broad ligament } \\
\text { hematoma }\end{array}$ & 3 & 0.65 \\
\hline LSCS with DIC & 3 & 0.65 \\
\hline Ruptured ectopic & 2 & 0.44 \\
\hline Adherent placenta & 1 & 0.22 \\
\hline Vesicular mole & 1 & 0.22 \\
\hline Sepsis & 52 & 11.32 \\
\hline PIH & 46 & 10.02 \\
\hline $\begin{array}{l}\text { Thrombo } \\
\text { embolism }\end{array}$ & 10 & 2.17 \\
\hline DIC & 10 & 2.17 \\
\hline MTP & 8 & 1.74 \\
\hline $\begin{array}{l}\text { Pulmonary } \\
\text { embolism }\end{array}$ & 5 & 1.11 \\
\hline $\begin{array}{l}\text { Amniotic } \\
\text { embolism }\end{array}$ & 2 & 0.44 \\
\hline Indirect causes & 295 & 64 \\
\hline Hepatitis & 129 & 28.10 \\
\hline $\begin{array}{l}\text { Cardiovascular } \\
\text { disease }\end{array}$ & 33 & 7.18 \\
\hline Kochs & 31 & 6.75 \\
\hline Infections & 24 & 5.23 \\
\hline $\begin{array}{l}\text { Respiratory } \\
\text { disease }\end{array}$ & 22 & 4.79 \\
\hline Anemia & 12 & 2.61 \\
\hline Liver disease & 11 & 2.39 \\
\hline Renal disease & 8 & 1.74 \\
\hline Febrile illness & 8 & 1.74 \\
\hline CNS disease & 7 & 1.52 \\
\hline $\begin{array}{l}\text { Hematological } \\
\text { disease }\end{array}$ & 3 & 0.65 \\
\hline Other causes & 7 & 1.49 \\
\hline
\end{tabular}

Table 4: Comparison with Indian statistic.

\begin{tabular}{|lll|}
\hline $\begin{array}{l}\text { Causes of } \\
\text { maternal } \\
\text { mortality }\end{array}$ & $\begin{array}{l}\text { Tertiary care } \\
\text { center data } \\
\text { 2008-2018 }(\%)\end{array}$ & $\begin{array}{l}\text { All over } \\
\text { India 1997- }\end{array}$ \\
\hline Direct causes & 35.75 & 66 \\
\hline Hemorrhage & 6.75 & 38 \\
\hline Sepsis & 11.32 & 11 \\
\hline Hypertension & 10.02 & 5 \\
\hline $\begin{array}{l}\text { Obstructed } \\
\text { labour }\end{array}$ & 0.43 & 5 \\
\hline Abortion & 7.19 & 8 \\
\hline Embolism & 5.88 & Not specified \\
\hline Indirect causes & 64.25 & 34 \\
\hline
\end{tabular}

\section{DISCUSSION}

According to RGI-SRS report of 2013 MMR in India has registered a decline from 212 in the period 2007-2009 to 167 in 2011-2013. Hence the rate of decline between 20072009 and 2011-2013 was 5.7\%. If MMR had declined with same pace, then India would have achieved an MMR of 140 per 100000 live births. However, based on world health statistics (WHS) 2016 the MMR of India is still 174/100000 live births. This accounts to losing 5 mothers every hour. India accounts for around $17 \%$ of the burden of global maternal deaths.

The MMR in present study was 1242 per 100000 live births, ranging from 824 in 2008 to 1072 in 2018 (Table 1). Most women were referred from peripheral hospital of Palghar district and nearby districts resulting in delayed intervention. Sundari et al tertiary care institution reported mortality rate of 559-802/100000 live birth due to large number of referral cases. ${ }^{5}$ Similar to present study. Level 1 delay $30 \%$, level 2 delay $40 \%$, level 3 delay $4 \%$ and no delay $26 \%$. We might have under estimated the levels of delay maternal mortality because death reporting was incomplete. Most deaths were observed in the 20 -30years age group in present study, this matches with study done by Pratima et al, Rajeshwari et al, Khandale et al and Murthy et al. ${ }^{8}$ Postpartum death were $48.58 \%$ and ANC deaths were $44 \%$. Young age group women were involved due to early marriage, poverty and nutritional deficiency.

In our study, multipara comprised $64.05 \%$ of maternal mortality, reflecting the need of strengthening family planning services, so that every pregnancy is by own wish and planned. Repeated pregnancies with in short span of time along with poverty, poor hygiene and nutritional deficiency.

In our study hepatitis was leading cause of death. Nair hospital is a multi-specialty hospital is situated in Mumbai central caters to high-risk pregnancies. It is a referral center for BMC/private hospitals in Mumbai and neighboring districts. Jaundice patients in third trimester were transferred to our hospital for OT facility, ICU management and blood bank availability. Out of 459, hepatitis $129(28.10 \%)$, sepsis $52(11.32 \%)$, PIH with eclampsia $46(1.02 \%)$, cardiac disease was $33(7.18 \%)$, obstetric hemorrhage $31(6.75 \%)$. In study done by Bhosale et al causes of maternal death were hemorrhage $24 \%$, sepsis $20.2 \%$ and hepatitis $17.5 \% .^{10}$ Also study done by Trivedi et al viral hepatitis $29.43 \%$, sepsis $20.09 \%$, anemia $10.74 \%$, PIH $7.94 \%$ and hemorrhage $7.94 \%$ were majority cause of maternal death similar to our study. However, many studies showed hypertension, sepsis and hemorrhage as causes of maternal death. ${ }^{5-8}$

Hepatitis patients clinically presented with hepatic encephalopathy in 81 , DIC in 22, fulminant hepatitis 14 and hepatic renal involvement in 12. There were antepartum 38 post abortion 5, postpartum 86 involving 2LSCS maternal death. Poor sanitation and elimination of 
sewage and unclean water and unhealthy food lead to viral hepatitis. In year 2015 and 2016 increase in viral hepatitis cases were seen. Majority of maternal death were due to viral infection.

Women with sepsis and PIH complication were referred in serious condition to our center. They were managed in ICU. Thrombo embolism related death needs to be reduced by timely use of heparin.

In our study obstetric hemorrhage contributed to $6.75 \%$ cases much lower than other Indian studies Rajeshwari et al $35.5 \%$, Murthy et al $26.66 \%$, Montogomery et al $27 \%$. $^{6-}$ ${ }^{8}$ This is probably because our center runs blood bank facilities round the clock with availability of blood components and timely management. In spite of doing 6 obstetric hysterectomies out of 23 cases of PPH maternal death occurred.

Anemia was a significant co morbid factor in most of women and indirect cause of maternal mortality in $2.61 \%$ cases. This led to increased morbidity. Irregular antenatal coverage and unmet dietary requirements of women especially in poor socioeconomic status.

Globally, direct obstetric causes and indirect causes have been implicated in 73 and $27.5 \%$ respectively. ${ }^{12}$

In India, maternal death direct cause is $66 \%$ and indirect cause are $34 \% .^{14}$

Our study is different as causes are reversed direct $35.75 \%$ and indirect $64.25 \%$.

There were large number of maternal death due to infection (Viral hepatitis 129, Kochs 31, HIV 7, malaria 8, dengue 7, H1N1 5 and leptospirosis 4, some cases had overlap of two infection), medical diseases and other causes.

\section{Limitations}

This study does not include data regarding the fact whether delivery happened at our hospital or at any other hospital.

Comparing this study to a national level-based data and report would be inappropriate due the smaller number of live births in our hospital in comparison to national data. Hence data of MMR cannot be extrapolated.

Large number of patients who died in the antenatal period falsely increase the MMR as they also falsely decrease the number of live births.

\section{CONCLUSION}

Most striking feature is that most of these deaths are preventable. Pre-existing medical condition and Infection gets aggravated by physiological effect of pregnancy complicating obstetric condition leading to maternal mortality. Increasing awareness of hygiene and different mode of transmission of various infections by rigorous health education. Enforcing basic obstetric care for all, strengthening referral linkage system with early transfer, emphasis on blood bank facilities and use of contraceptive measures will help in reducing maternal mortality. NRHM policies, Janani Suraksha Yojana and Janani Shishu Suraksha Yojana have increased focus on providing no expenses for delivery and transport. Pradhanmantri Mantri Matrutva Vandana is implemented to provide money in post-delivery period for wages loss. This will cause surge in institutional deliveries and prevent anemia and low birth weight baby. It is essential to identify problems in the system contributing to maternal death. District level maternal death review meetings will be a beneficial tool for planning health care.

LaQshya program was launched in $11^{\text {th }}$ December 2017 to improve quality of care in labour room and maternity OT. Obstetric ICU should be started in medical college.

SUMAN (Surakshit Matrutva) yojana-Zero preventable maternal and new born death and high quality of maternity care delivered with dignity and respect.

\section{ACKNOWLEDGMENTS}

Author would like to thank all the faculty/staff members of department of gynecology and obstetrics for participating in maternal mortality meetings.

Funding: No funding sources

Conflict of interest: None declared

Ethical approval: The study was approved by the Institutional Ethics Committee

\section{REFERENCES}

1. World Health Organization. The WHO application of ICD-10 to deaths due to pregnancy, childbirth and puerperium: ICD MM. 2012.

2. United Nations. UN Millennium Development Goals web site. Available at: http://ww.un.org/mellineum goals/. Accessed 1 August 2009.

3. Park K. Preventive medicine in obstetric, pediatrics and geriatrics: Park's text book of preventive and social medicine. 2015;24.

4. United Nations Millennium Development Goals Report. 2015.

5. Sundari KP, Jayanthi RD, Ramasamy B. Trends in maternal mortality in a tertiary care hospital. Int $\mathbf{J}$ Reprod Contracept Obstet Gynecol. 2016;5:3659-62.

6. Shobha R. Maternal mortality in an urban tertiary care hospital of south India. Indian J Obstet Gynecol Res. 2016;3(1):32-7.

7. Khandale SN, Kedar K. Analysis of maternal mortality: a retrospective study at tertiary care centre. Int J Reprod Contracept obstet Gynecol. 2017;6:16103 . 
8. Murthy BK, Murthy MB. Maternal mortality in tertiary care hospital: a 10-year review. Int J Prevent Med. 2013;4(1):105-9.

9. Montgomery AL, Ram U. Kumar R. The million death Study Collaborators. Maternal mortality in India: causes and healthcare services are based on a Nationally Representative Survey. PLoS ONE. 2014:9(1):e83331.

10. Bhosale A, Qureshi S, Nandanwar Y. Maternal Mortality at tertiary institute. Bombay hospital $\mathrm{J}$. 2011;53:2:189A.

11. Gupta TG. Study of Maternal mortality due to Viral hepatitis Obstetrics and gynecol India. 2003;53(6):551-3.

12. Lale S, Doris C, Alison G. Global causes of maternal death; a WHO systematic analysis. Lancet Glob Health. 2014;2(6):e32-3.
13. Ministry of health and family welfare Maternal Health Program. Available at: www.mohfw.nic.in/1892S/Chapter415/write READ DATA/1892S/CHAPTER415. Accessed on 10 March 2021.

14. RGI CGHR SRS causes of maternal death from 2001 to 2003. Available at: cghr.org/word press/wp content. Accessed on 10 March 2021.

Cite this article as: Saravade VR, Ansari M, Shinde G. Analysis of causes of maternal mortality in tertiary care center, 11 years study. Int J Reprod Contracept Obstet Gynecol 2021;10:3320-4. 